\title{
Muxama and other traditional food products obtained from tuna in south Portugal and Spain: review and future perspectives
}

\author{
Eduardo Esteves ${ }^{1,2^{*}}$ (D) and Jaime Aníbal ${ }^{1,3}$
}

\begin{abstract}
There is evidence that consumers perceive fish as healthy (Carlucci D et.al, Appetite 84:212-27,2015; Vanhonacker F et.al, Br Food J 115:508-25,2013; Verbeke W et.al, Public Health Nutr 8:422-9,2005.). Historically, the development of (traditional) processing techniques allowed for the preservation of excess quantities of fresh fish for storage or transport. Those technologies are not well documented and are being lost with the trend to urbanization and consumption of convenience, ready-to-eat food. In the so-called developed world, there is still a considerable demand for traditionally processed (sea)food products, wherein the raw material and the final product are of high value. Muxama or mojama is a traditional, highly valued food product prepared from dry-cured tuna loins that is a delicatessen in the southern Iberian Peninsula: Algarve (Portugal) and Andalucía, Murcia, Alicante, and Valencia (Spain). The tuna (mostly Thunnus obesus and T. albacares) loins are salted and dried following a typically artisanal process that incorporates empirical knowledge passed down numerous generations since at least the tenth century Common Era (Aníbal J and Esteves E, Muxama and estupeta: traditional food products obtained from tuna loins in South Portugal and Spain, Traditional food products 2016, Lindkvist KB et.al, Can Geogr-Géogr Can 52:105-20,2008, Gallart-Jornet L et.al, La salazón de pescado, una tradición en la dieta mediterránea The salting of fish, a tradition in the Mediterranean diet] 2005.). The production process changed little over the years but is different among locations, even supporting distinct certifications. The stability of muxama derives from the reduced water activity. Furthermore, the drying method has secondary effects on flavor, color, and nutritional value of the product. In southern Portugal and Spain, muxama is the prime food product obtained from tuna at the end of the traditional quartering of tunas, named ronqueamento in Portugal or ronqueo in Spain. Other food products obtained from tuna include Estupeta, Mormos, Rabinhos, Faceiras and Orelhas, Ventresca, Tarantela and Sangacho, Espinheta, Tripa, Bucho, and Ovas. These products result from employing different manufacturing procedures and processes. In this paper, we tentatively describe the main features of the processing stages and traditional food products obtained from tuna produced in the southern Iberian Peninsula (Portugal and Spain) and discuss the interactions of knowledge systems and transmission of traditional knowledge regarding its production.
\end{abstract}

Keywords: Muxama, Mojama, Salted-dried tuna loins, Traditional food products, Tuna, Production and perspectives

\footnotetext{
* Correspondence: eesteves@ualg.pt

'Departamento de Engenharia Alimentar, Instituto Superior de Engenharia, Universidade do Algarve, Faro, Portugal

${ }^{2}$ CCMAR, Centro de Ciências do Mar, Universidade do Algarve, Faro, Portugal

Full list of author information is available at the end of the article
}

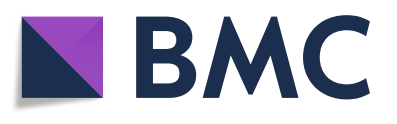

(c) The Author(s). 2019 Open Access This article is distributed under the terms of the Creative Commons Attribution 4.0 International License (http://creativecommons.org/licenses/by/4.0/), which permits unrestricted use, distribution, and reproduction in any medium, provided you give appropriate credit to the original author(s) and the source, provide a link to the Creative Commons license, and indicate if changes were made. The Creative Commons Public Domain Dedication waiver (http://creativecommons.org/publicdomain/zero/1.0/) applies to the data made available in this article, unless otherwise stated. 


\section{Introduction}

There is evidence that consumers perceive fish as healthy [1-3]. Portugal and Spain are countries with relatively high seafood consumption compared to other countries in Europe and two of the largest in the world [4]. However, knowledge of which species are most consumed and their trends and forcing factors is scant $[1,5,6]$. Historically, the development of (traditional) processing techniques allowed for the preservation of excess quantities of fresh fish for storage or transport. Those technologies are not well documented and are being lost with the trend to urbanization and consumption of convenience, ready-toeat food. In the so-called developed world, despite the shift towards (more) convenient forms of fish and seafood consumption, there is still a considerable demand for traditionally processed (sea)food products [1], such as muxama and other products derived from tuna, wherein the raw material and the final product are of high value (e.g., in Spain, the average price of tuna and bonitos during 2017 was $9.66 € / \mathrm{kg}$ compared to $6.67 € / \mathrm{kg}$ for other seafood [7], and the muxama/mojama is sold online between 35 and $54 € / \mathrm{kg})$.

In the following sections, we give first a brief overview of the fishery that sustains the traditional production of muxama and other tuna-based products in the southern Iberian Peninsula. Then, we present several fresh and "minimally processed" tuna products. Traditionally, the processing of fish and seafood is centered on curing methods such as salting and drying. Thus, we provide an overview of such methods and, then, present a number of traditionally processed tuna-based products.

In this paper, we tentatively describe the main features of the processing stages and the characteristics of traditional food products obtained from tuna that are produced in the southern Iberian Peninsula (Portugal and Spain).

\section{Fishing, aquaculture, and quartering}

Different species of fish are categorized as tuna, a generic name for individuals from the Scombridae family, mostly from the genus Thunnus. Tunas are widely but sparsely distributed throughout the oceans of the world, usually occurring in tropical and temperate waters between about $45^{\circ}$ North and South and constitute a very important commercial resource [8]. The warm-blooded adaptations displayed by some species of tuna that can raise their body temperatures above surrounding water temperatures due to high muscular activity [9], allows them to survive in cooler ocean environments and to inhabit a wider range of latitudes than other kinds of pelagic fish.

In 2016, the principal species of tuna for commercial and recreational fisheries were, in decreasing order of contribution to the catch, skipjack (Katsuwonus pelamis), yellowfin
(Thunnus albacares), bigeye (T. obesus), albacore (T. alalunga), and bluefin tuna (T. thynnus, T. orientalis, and $T$. maccoyii). Their catch (about five million tonnes) represented ca. two thirds of the total catch of all tuna and tunalike species that tallied 7.4 million tonnes [10]. A minute fraction of the worldwide catch corresponded to landings in Portugal (ca. $4800 \mathrm{t}$ ) and Spain (272,000 t) (Fig. 1). Of these, only 40 tonnes of yellowfin tuna were reported by Portugal's INE [11] as being cultured, surely in the armação (or almadraba in Spanish) set off Olhão (Algarve, Portugal). In contrast, Atlantic bluefin tuna is of particular interest to the almadraba fishery in southern Spain. In 2010, Gonzalez and Acevedo [12] report substantially high catches for those almadrabas gaditanas (Gulf of Cadiz, Spain) (5142 t). Besides being European Union's (EU) largest producer of fisheries and aquaculture products [13] Spain is a leading producer of cultured, fattened Atlantic bluefin tuna, mostly for export to the Japanese market. According to the Food and Agriculture Organization of the United Nations (FAO), about 2760 t (equivalent live weight) were expedited to Japan from Spain in 2012, of which ca. $555 \mathrm{t}$ (equivalent live weight) corresponded to weight gained while being kept and fed in marine cages [14].

Seemingly, canned tuna and sashimi/sushi are the products that drive the global production of tuna. Thailand is by far the largest exporting country of processed tuna, followed by Ecuador, Spain, Indonesia, and the Philippines. The main markets for canned tuna are the USA, the European Union, Egypt, Japan, and Australia. On the other hand, the sashimi/ sushi market is another main destination of tuna, specially of the high-valued bluefin. Japan is the principal importing country of bluefin tuna but other countries like the USA, Spain, and Italy have increased its consumption. It is the preferred species for sashimi/sushi in Japan for its high fat content, but prices have been rising due to scarcity as stocks are under conservation measures. According to FAO's GLOBEFISH unit, the relatively recent advent of aquacultured bluefin tuna constitutes a more affordable alternative for Japanese consumers [15].

Most of the 14,359 $\mathrm{t}$ of processed tuna in Portugal in 2016 were canned (in olive oil or other oils) for Human consumption. In neighboring Spain, the seafood industry produced an overwhelming quantity of 220,000 $t$ of canned tuna in 2016. There are no explicit statistical records for utilization or trade of tuna in the dry-salted (seafood) product categories in Portuguese statistics [16]. Contrariwise, the Spanish Ministry of Agriculture and Fisheries, Food and Environment (MAPAMA) [17] reports a production of $1260 \mathrm{t}$ of dried, salted, brined, or smoked tuna (including skipjack).

In 2014, 65.7\% of the world production of tunas was caught by purse seiners, $27.4 \%$ by longline, about $5.0 \%$ by gill nets and surrounding nets, and the remainder by a variety of other gears [18], namely thru fixed gears. In the 


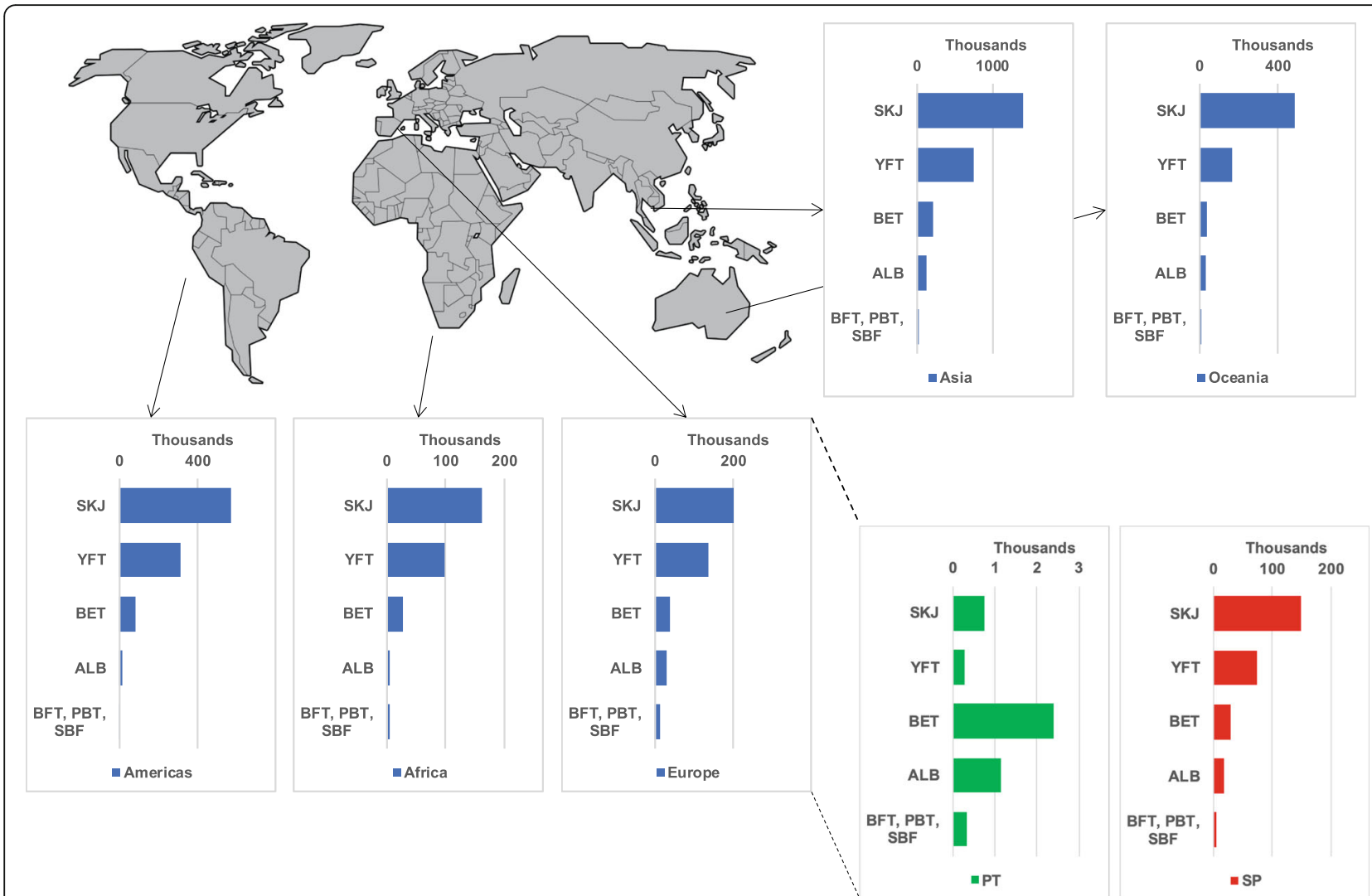

Fig. 1 Distribution of catches (thousands of tonnes) per species of tuna and per continent in 2016 (data from [10]). Note different $x$-axis scales for charts. SKJ skipjack, YFT yellowfin tuna, BET bigeye tuna, ALB albacore, BFT Atlantic bluefin tuna, PBF Pacific bluefin tuna, SBF Southern bluefin tuna, PT Portugal, SP Spain

south of the Iberian Peninsula (Algarve and Andalucía), tuna was traditionally caught using a fishing gear named almadraba, i.e., an offshore maze of bottom-fixed nets to imprison, capture, and hold the fish (Fig. 2). Changes in the migratory patterns of tuna schools, arguably due to climate change [23], were probably the main reason leading to declining catches and the disappearance of this kind of fishing method during the 1960s in Portugal [24]. While operating and prospering, the numerous almadrabas established in Portuguese and Spanish waters supplied raw material for the canned tuna plants that became an important regional economic asset, creating significant employment $[24,25]$. Interested readers are referred to [26-28]. There are historical video documentaries about the day-to-day life in Portuguese and Spanish almadrabas that are viewable online. Today, "Spain leads the production of canned food, [particularly of tuna,] in the EU" but has to rely heavily on imports of raw material, e.g., tuna from Ecuador or tuna loins (free of tariffs) from Thailand, Indonesia, and the Philippines [29]. To our knowledge, only one, privately owned almadraba [19] is currently operating off Algarve (Fig. 2), 2.5 nautical miles from the coast at $20-60 \mathrm{~m}$ depth. Therein, besides fishing and maintaining adult specimens, undersized tunas are fed (and fattened) with low-valued, fat fish species, e.g., mackerel. Presently, there are four almadrabas in operation off Barbate, Tarifa, Zahara de los Atunes, and Conil de la Frontera (Andalucía, Gulf of Cadiz, Spain) (Fig, 2). These are privately owned and run almadrabas that are associated into OPP51-Organización de Productores Pesqueros de Almadrabas [20]. Similarly, tunas are kept and fed trying to increase the fat content of their meat by supplying natural food for a certain time.

The traditional quartering of tuna in the southern Iberian Peninsula is a meticulous, spectacular, and millenary technique. Drawings in Aegean Sea pottery (third to fourth century Before Common Era, BCE) [30, 31], Roman literary sources [32] and archeological records dated to the fifth century CE (e.g., [33]) suggest the development of a cutting system of large predators, like tunas, in the Mediterranean area. The traditional quartering of tuna is designated ronqueamento in Portugal (ronqueo in Spain), and the very word is an onomatopoeia since it is supposedly due to the noise that the knife makes when cutting close to the spine of the fish. It is carried out manually, following a sequence of cuts 


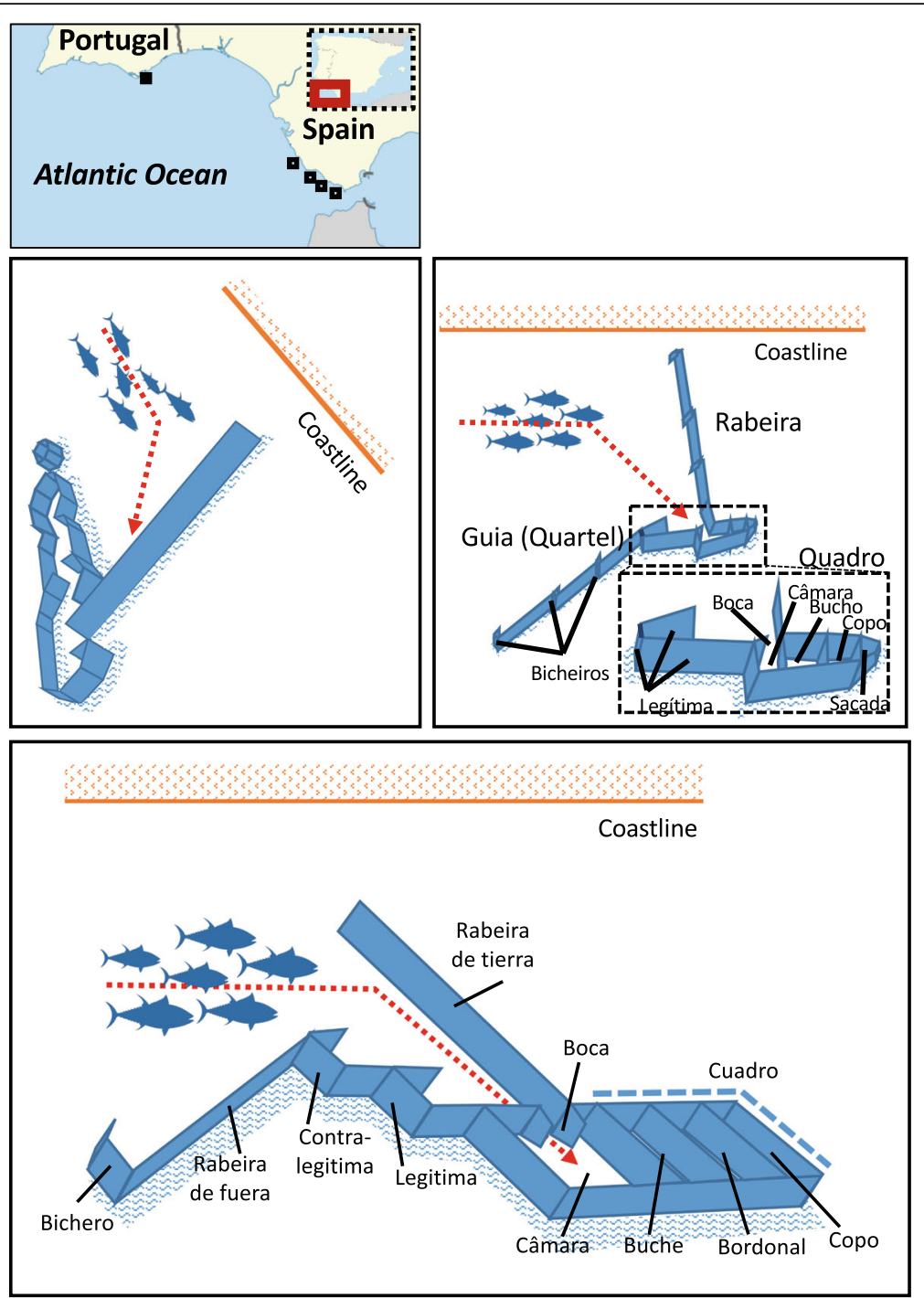

Fig. 2 Diagrammatic representations of the alamdrabas fishing off the Algarve today (middle left) and until the 1960s (middle right; designations in Portuguese), and off the Gulf of Cádiz (bottom; designations in Spanish), as well as (approximate) localization of the alamdrabas still operating in Portugal (black square) and Spain (white square) (top) (adapted from several sources, [19-22])

that depends primarily on the degree of fatness that the muscle presents, not necessarily following differentiated muscle pieces. The different parts of the tuna are extracted both for fresh consumption and for the further production of (more) elaborated products. A cursory search of the Internet using "ronqueamento atum" or "ronqueo atun" will give a number of links to photo galleries and videos of the quartering.

\section{Fresh and "minimally processed" tuna products}

Numerous books [34-42] provide a comprehensive presentation of quality characteristics and deterioration of fish and seafood products. For a recent, introductory and relatively brief account about fish freshness and spoilage see [43].
Seafood products are marketed and consumed in a wide spectrum of forms (chilled fresh, modified atmosphere packed, marinated, salted, dried, canned, etc.) in order to fulfill consumers' demands. Other, emerging technologies, such as high-hydrostatic pressure, ionizing radiation, chitosan coating, and novel packaging forms are becoming widely used [44].

In the southern Iberian Peninsula, there has been essentially three different ways of consuming tuna: fresh, e.g., as tuna steaks; canned, for example in olive oil; and cured, i.e., salted and/or dried in the form of muxama. As with other seafood, fresh tuna spoils quickly owing to its high protein content, more so if subjected to high temperatures [39] commonly occurring during Summer. Since refrigeration systems only became ubiquitous in 
the food industry (and available to typical consumers) in the last 50 or 60 years, alternative methods were used in the past to preserve (sea)food. Thence curing, namely salting and drying, were important processes for preserving tuna for longer periods outside the fishing season that spanned from April to September [24].

To our knowledge, there is no traditional product or dish prepared with raw tuna in the southern Iberian Peninsula. Until relatively recently, the consumption of fresh, raw tuna in Portugal and Spain was marginal and mostly for connoisseurs, but according to FAO's GLOBEFISH unit there is an increasing demand for sushi/sashimi worldwide [15], with the number of restaurants and related establishments evidently increasing every year.

The particular style of today's sushi, Nigiri-zushi (rice ball with vinegar and raw fish) which main ingredients are raw fish and rice (besides gari, pickled ginger, and nori, seaweed wrapper), became popular in Edo (contemporary Tokyo) in nineteenth century Japan [45], but the first record regarding Nare-zushi (salted-then-fermented fish) in Japan dates to year 718 [46]. Commonly used fish for sushi are tuna (maguro, shiro-maguro), Japanese amberjack, yellowtail (hamachi), snapper (kurodai), mackerel (saba), and salmon (sake). The most valued sushi ingredient is toro, the fatty cut of the fish (corresponding approximately to ventresca and tarantela; see the "Traditionally processed tuna-based products" section). Many non-Japanese use the terms sashimi and sushi interchangeably, but the two dishes are distinct and separate. Sushi refers to any dish made with vinegared rice, while sashimi is, essentially, sliced seafood popularly served with a dipping (soy) sauce and condiments such as with wasabi paste and grated fresh ginger [47].

Carpaccio is an Italian, Piedmont-based specialty dish made of raw meat or fish (such as beef, veal, salmon, or tuna), thinly sliced and served with lemon, olive oil, and white truffle or Parmesan cheese, mainly as an appetizer [48].

Poke (Hawaiian for "to slice or cut") is a raw fish salad usually served as an appetizer in Hawaiian gastronomy, and sometimes as a main course. Traditional forms are $a k u$ (an oily tuna), he'e (octopus), and ahi (fresh tuna). Ahi poke is normally made with bigeye (T. obesus) and yellowfin (T. albacares) tuna [49].

Hoe-deopbap or raw fish bibimbap (mixed rice) is a Korean dish consisting of steamed rice mixed with sliced or cubed raw fish, various vegetables such as lettuce, cucumber, and sesame leaves; sesame oil; and a sauce made from vinegar, gochujang (a red chili paste), and sugar. The fish used for making hoe-deopbap is generally either halibut, sea bass, rockfish, tuna, salmon, or whitefish [50].

In Europe, there is increasing interest in traditional fish products derived from local species and prepared using ancient, traditional recipes and methods [51]. Moreover, the development of gastronomy and the advent of fusion and nouvelle cuisine together with the growing market demand for innovative (sea)food products or alternative, sustainable fish species, led to the introduction of novel, unconventional species (or products) into chefs recipes (e.g., [52-54]).

Gravad lax (or gravlax) is a Nordic dish consisting of raw fish, cured in salt, sugar, and dill. Normally done with salmon, it can also be prepared with other fatty fish, eventually tuna. Gravlax is usually consumed as an appetizer, thinly sliced, and accompanied by a dill and mustard sauce, either on bread, or with boiled potatoes [55].

Ceviche is a Peruvian seafood dish popular in the coastal regions of Latin America and the Caribbean that resembles Japanese sashimi. It is typically made from fresh raw fish cured in citrus juices, such as lemon or lime, and spiced with aji (chili peppers), and usually accompanied by side dishes that complement its flavors, such as sweet potato, lettuce, corn, avocado, or plantain [56]. The use of fresh, raw tuna for the preparation of ceviche is referred to in a number of books (e.g., $[57,58])$ and a cursory online search for "ceviche atum" and "ceviche atún" gives hundreds of results.

\section{Processed tuna}

\section{Drying and salting of seafood: a brief overview}

Drying is one of the earliest known methods of preserving food, namely fish and other seafood, devised by humans [59-61]. Drying (often sun-drying), together with salting (or brining), smoking, acid curing/fermentation, or a combination of these methods, sometimes categorized as curing (e.g., [37, 62]), have been practiced longer than any other food preservation technique [63], e.g., fish were caught and dried by people in Solvieux (southern France) during the Mesolithic age (ca. 10,000 BCE) [64], the ancient Egyptians may have been the first to purposefully cure meat and fish with salt and the earliest Chinese record of preserving fish in salt date from ca. 2000 BCE [65]. Since their inception as preservation methods applied to numerous food products, namely fish and other seafood-derived products, curing methods have been developed and quite a few endured the test of time, becoming traditional fish products in many countries worldwide [44].

Drying is "the single most common unit operation in the food industry" [66] for processing and preservation of (sea)food products and is a well-understood physical process [67]. Commonly preceded by a "preparatory" dry salting or brining stage or pre-treatment (see below), salting and drying work by decreasing the availability of water (and, in some products, lowering the $\mathrm{pH}$ ) that in fish and seafood easily reach $80 \%$ [63]. During salting, the diffusion of salt into the fish muscle where it bonds with tissue's water and thus depresses the availability of unbounded, "free" water or water activity $\left(a_{\mathrm{W}}\right)$ [63]. Subsequent drying further accentuates this effect on $a_{\mathrm{W}}$, 
since penetrating heat promotes the movement of water from the interior of the muscle towards the surface where it is then removed, as vapor, from the surface layer [61]. As a consequence, microbial growth as well as undesirable chemical reactions induced by enzymes is inhibited, in a sense acting as a preservative [68]. Most microorganisms are inhibited at $a_{\mathrm{W}} \leq 0.60$ and hydrolytic reactions and enzyme activity are quite reduced at those levels of $a_{\mathrm{W}}$ (Fig. 3). These effects facilitate storage (at ambient temperature), transportation, and consumption of products.

There are different types of salting processes [37, 70] namely brining, pickling, kench curing (dry salting), Gaspé cure, and wet salting. The salt to be used in salting is a determinant factor for final products' quality, namely its origin, chemical composition, and dimensions of salt crystals [71, 72]. In addition, there are a number of drying methods appropriate for fish and seafood that can be categorized according to several criteria, e.g., air or contact drying, vacuum drying, and freeze drying [37, 73], and there is a large range of types of dryers, e.g., drum, rotary, tray, cabinet $[64,74,75]$.

The salting and drying processes have profound impact on the characteristics of the products [61, 76-79]. Rahman [[75]; Table 25.1] summarizes the quality characteristics of dried foods. Furthermore, salted-dried products incorporate flavor-texture-color combinations and nutritional value that are unique and highly valued by consumers [59, 63, 66, 67, 73, 76, 80-90]. Dried and salted fish are very popular food items worldwide. Wikipedia [91] lists more than 20, e.g., bacalhau (salteddried cod, [84]), vobla (salted-dried roach), litão seco [83, 92], or muxama (salted-dried tuna, [82, 92, 93]).
Notwithstanding, today the demand is impelled more for the flavor of the product than for preservation purposes [73, 94-96].

\section{Traditionally processed tuna-based products}

A number of salted and cured products can be obtained from tuna (mostly bluefin tuna T. thynnus, and yellowfin tuna, T. albacares, but also albacore, T. alalunga, and bigeye tuna, $T$. obesus), "one of the fishes more widely salted since antiquity". Almost every part of a tuna can be utilized (73\% of body weight according to Gallart-Jornet et al. [30]), with a great variety of products being traditionally prepared from its distinct parts [25, 30, 93, 97]: mormos, faceiras (faseras in Spain), lombos (descargamento, descargado, solomillo, and plato or lomo), ventresca (ijada), tarantela (tarantelo), estupeta, rabinhos (cola blanca and cola negra), espinhaço (espinazo), espinheta (espineta blanca and espineta negra), bucho (buche), ovas (huevas), tripas (recortes), and sangacho (Fig. 4). These are obtained from a tuna at the end of the (traditional) quartering of specimens a.k.a. ronqueamento (or ronqueo) (see the "Fishing, aquaculture, and quartering" section). Presently, the highest-priced products are muxama (mojama), ovas (huevas), ventresca (ijada) and lombos descargamento, descargado, and plato or lomo) [30]. For the interested readers, [101] studied the lexicon associated with tuna and tuna-derived products referred to above to find that it is a symbol of Mediterranean culture.

Muxama (in Portugal) (named mojama in Spain, or mosciame in Italy), is probably the emblematic food product obtained from processing tuna in the southern Iberian Peninsula, i.e., in the Algarve (Portugal) and in Andalucía, Murcia, Alicante, and Valencia (Spain) (Fig. 5). It

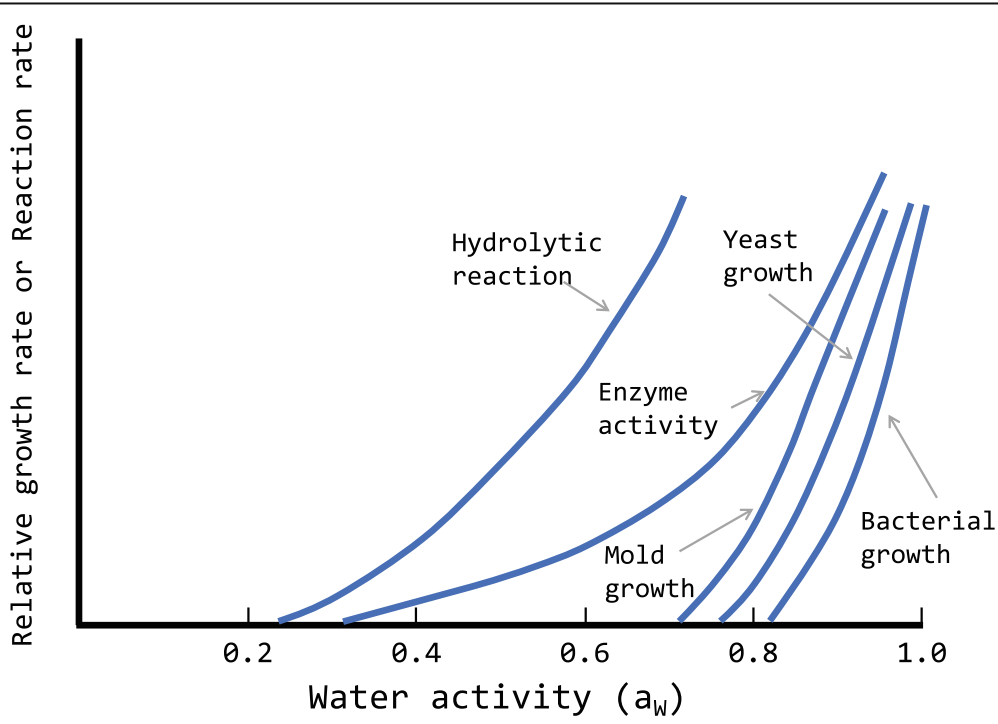

Fig. 3 Idealized curves of changes in relative growth rate of microorganisms and reaction rate versus water activity level (adapted from [69]) 


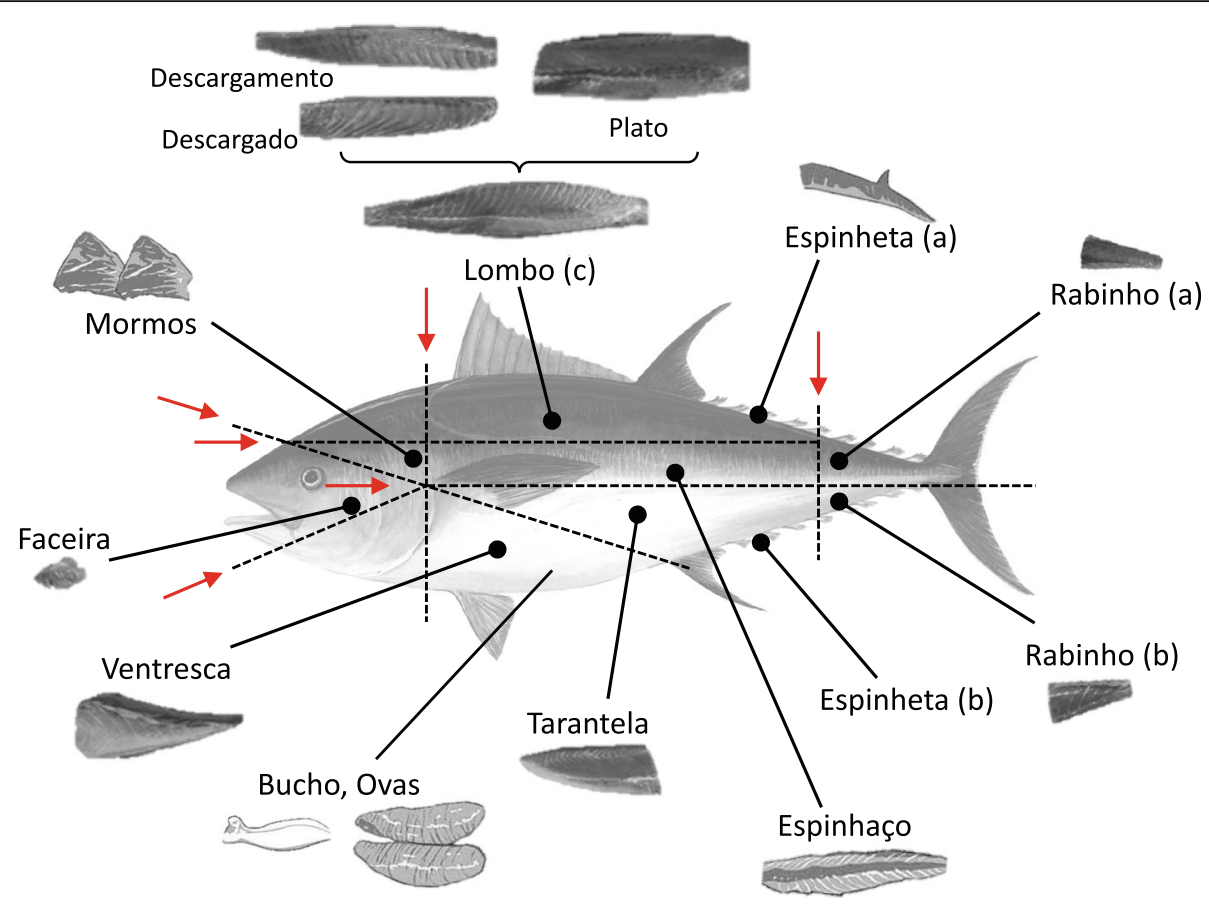

Fig. 4 Parts of (bluefin) tuna resulting from the traditional quartering (ronqueamento or ronqueo) in the southern Iberian Peninsula (adapted from several sources [98-100]). Red arrows and dashed lines illustrate directions of main cuts during quartering. Refer to main text for further explanation about designations (in Portuguese above). (a) upper (black), (b) lower (white), and (c) loins are further separated into (sub)parts, the inner, valuable descargamento (upper), and descargado (lower) loins used to produce muxama, and the outer muscle, named plato or lomo used to prepare sushi/sashimi
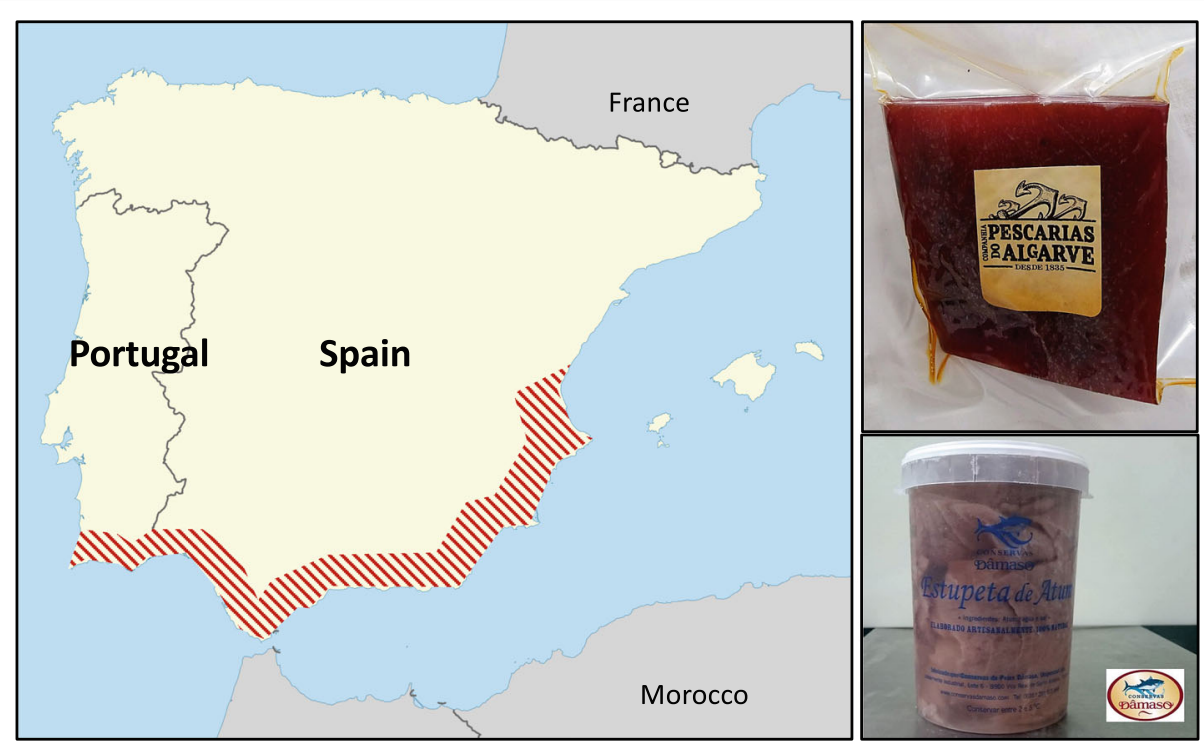

Fig. 5 Map of the Iberian Peninsula with area of interest (orange shaded area) for muxama and related tuna-based products marketed in southern Portugal and Spain (left) and photos of the products: packed muxama distributed in the Algarve by Companhia de Pescarias do Algarve SA but produced in Spain; top right) and jar of estupeta produced in the Algarve by Conservas Dâmaso Lda (bottom right) 
is a highly priced delicatessen obtained from dry-curing tuna loins of wild and large ( $>200 \mathrm{~kg}$ live weight) yellowfin and bluefin tunas that can be fished worldwide $[102,103]$ and arrive frozen at the plants $[25,88]$, instead of being fished using an off-shore maze of bottom-fixed nets to imprison, capture, and hold the fish named an armação (or almadraba) [26] (see the "Fishing, aquaculture, and quartering" section).

Using a largely artisanal procedure that incorporates empirical knowledge passed down numerous generations since at least the tenth century CE [93] or even earlier-in pre-Roman times and during Roman rule over Hispania (second century to fourth century BCE) [30, 104]-the tuna loins are salted and dried in a series of steps that are described in [25, 30, 93] and more recently in Esteves [92]. Succinctly, after quartering the trimmed tuna loins are stacked and salted in alternate layers of salt for a day or two (traditionally the piles were hard-pressed with large, heavy stones). Afterwards, salted loins are washed in tap water until all visible salt crystals are removed from the surface and left to stand again for a day or two. When loins are firm enough, they are hanged to dry at about $14{ }^{\circ} \mathrm{C}$ and $60 \%$ humidity for up to 12 days. Portions, 80 $100 \mathrm{~g}$ to $>1 \mathrm{~kg}$, are marketed packed in vacuum-sealed polyethylene bags or trays or, otherwise, in jars dipped in olive oil. Muxama is cut into thin slices pretty much like ham and served as an appetizer [30, 93] (Fig. 5).

Companies producing muxama in Algarve (e.g., Conservas Dâmaso) and Andalucía (e.g., La Chanca or HERPAC) are mostly family-owned businesses. Apparently, at the outset, the production process and products' quality relied heavily on "tacit knowledge" (sensu [105]) of older, more experienced family-members and/or collaborators. Their individual know-how and expertise resulted most probably from sharing, e.g., apprenticeships-socialization [105]. This knowledge, about raw materials, procedures, or quality attributes, etc., was transmitted across generations for ages but within the coastal communities closely related to the almadrabas fishing for tuna. More recently, business management concerns and market demand together with stricter regulations (e.g., EU regulations on food safety) and standards/certifications (e.g., Protected Geographical Indications, PGI) drove businesses, that are managed by younger family-members or collaborators, to explore new, technology-based procedures (e.g., humiditycontrolled drying chambers) and assess products' quality parameters thru laboratorial techniques (e.g., $a_{\mathrm{W}}$, salt and histamine content). These are surely detailed in the technical sheets included in quality manuals (a propos quality systems and certifications) and have been studied and described in academic texts (e.g., [30, 88, 92, 93])—externalization [105]. Seemingly, at present, the issues challenging the transmission of knowledge found by Uchiyama et al. [106] in apiculture have been overcome; however, the remaining steps of the "knowledge conversion framework" referred to by Kohsaka et al. [105], combination and internalization, have yet to be implemented. The study of the relationships between traditional and modern scientific knowledge regarding the production of muxama in South Portugal and Spain using the approach of Kohsaka et al. [105] would be interesting. Furthermore, the analysis of certifications at the regional or landscape level and at the product level, sensu Kajima et al. [107] may well be carried out.

Notwithstanding the generalized steps described above, there are differences in the muxama's production process among locations. These differences allowed the registration of two Protected Geographical Indications (PGI), Mojama de Barbate and Mojama de Isla Cristina, within the European Union's quality schemes for agricultural products and foodstuffs abbreviated as PDO (Protected Designation of Origin), PGI (Protected Geographical Indication), and TSG (Traditional Specialty Guaranteed) [108] by two municipalities in Andalucía (Spain), Barbate and Isla Cristina $[102,103]$. Therein, interested readers will find the distinguishing characteristics of the products in terms of appearance/color, salt content, and relative moisture that endorse the registration as PGI. Moreover, this place-based, product-level certificate is promoted by the Consejería de Turismo y Deporte de la Junta de Andalucía (Spain) - the regional organization for tourism (www.andalucia.org) - as part of the "Ruta del Atún de Almadraba" (Route of Almadraba Tuna) and was incorporated in "Ruta Milenaria del Atún" [109], a "marketing project for an experiential tourism product" that is connected with production (fishing using almadrabas), processing (quartering, ronqueo, of tuna), and gastronomy. Indeed, this approach is expected to further establish the "placeness of regions" [107].

Besides muxama, a number of other products can be obtained from tuna. In fact, per $100 \mathrm{~kg}$ of tuna, it is possible to use about $61 \mathrm{~kg}$ of prime-quality muscle, $8 \mathrm{~kg}$ of lesser-quality meat, and $4 \mathrm{~kg}$ of viscera [30]. From the lesser valued muscle parts, other products are prepared, notably estupeta, lombo (different from muxama), ventresca (or ijada) from the belly, sangacho and rabinhos (cola branca and cola negra) (Fig. 4). Estupeta results from brining for at least 30 days [25] in a $10-25 \% \mathrm{NaCl}$ solution the narrow pieces of white, lipid- and fiber-rich muscle closely located to the dorsal loins described above [93]. Estupeta is commercialized in light-brine solution packed jars or buckets and constitutes the main ingredient in an Algarvian typical cold salad with minced tomato, sweet pepper, and onion, seasoned with olive oil and vinegar $[93,110]$. On the other hand, atún de tronco (the central part of the loins not used for muxama), sangacho (i.e., the dark, blood-rich meat beneath the lateral line), and ventresca (or ijada, i.e., the muscle part covering the viscera, belly) (Fig. 4) are salted in alternate layers of salt inside bins for 2 weeks to several months 
without drainage of exudates. Then, washed in the resulting brine to remove excess solid salts and drained, they are placed in barrels, again in alternate layers of salt. Barrels are sealed and let to cure at $15-18{ }^{\circ} \mathrm{C}$ for as long as determined by the salazonero. Exudated fat is collected and the volume equilibrated with newly added brine. Atún de tronco is used in typical Valencian (Spain) dishes named titaina and coca de tomaca en tonyina whereas ventresca is consumed simply sliced as an appetizer or as tapas [30]. From the viscera, notably the roe and the stomach are consumed. The female roe originates ovas (or huevas in Spain or bottarga in Italy) and from the stomach bucho (or estómago seco-salado) is obtained. The roe of tuna is washed and then salted in piles for 24-48 $\mathrm{h}$ depending on size and letting the exudate drain. After a gentle wash, they are salted again now compressed for 2-5 days. Finally, they are dried for a week and then the ovas are vacuum-packed for commercialization [111]. The ovas are consumed as thin slices seasoned with olive oil. On the other hand, the stomachs are split open, washed thoroughly, and dry salted in piles for 1-4 weeks. Then, excess salt is lightly washed in successive changes of water and the stomachs are left to dry (and become bucho). For consumption, firstly, the bucho is desalted in water for up to $72 \mathrm{~h}$ with water being changed every $12 \mathrm{~h}$. After a preparatory frying, they are cooked as a stew (eventually with beans or chickpeas).

The work by Gallart-Jornet et al. [30] constitutes a reference for these products in the Mediterranean region and provides further information about the nutritional composition, storage conditions, and parameters of (spoilage) quality control.

\section{Conclusions}

According to Sabarez [64] the drying processes that are currently employed in the food industry, including seafood, are still worthwhile and have not reached their limit of performance. There is still space for improvements, thru reengineering and optimization, in order to make processes more sustainable. Thus, drying shall continue to play a prominent part in manufacturing as the food industry readily embraces incremental improvements to the existing technologies.

Natural, open-air drying, still carried out in many locales for traditional seafood products, is at the mercy of the weather to affect the process and hardly any control is possible other than physical protection of the drying fish. Evidently, artificial or mechanical drying will give better control of temperature and air flow. These are already in use in several cases, namely for muxama and other tuna-derived products.

Gallart-Jornet et al. [30] and Esteves [92] compiled data on nutritional composition, products' characteristics, and quality parameters of raw tuna and muxama from which (the expected) changes due to processing can be inferred. Also, the production process has been studied by Barat and Grau [88] that carried out a number of experiments to characterize and compare the simultaneous thawing and salting of frozen tuna loins by using dry salt or brine to the traditional procedure described above. Those authors observed a clear shortening of the processing time required to obtain muxama with the simultaneous brine thawing and salting of frozen tuna loins. Moreover, Esteves and Aníbal [82] modeled the changes in physicalchemical parameters of tuna loins during the dry-salting stage and derived predictive equations to estimate parameters of interest by plugging-in values of temperature and time in the appropriate range (respectively 14 to $20^{\circ} \mathrm{C}$ and 4 to 7 days) during the subsequent drying stage of processing muxama. Studying the changes in quality parameters during/along processing and model the kinetics of chemical mechanisms in operation, instead of "simply" evaluating the characteristics thru analyses of end-products, as suggested by Collignan et al. [112] for osmotic dehydration of fish, would provide a broader understanding of quality development. Notwithstanding, changes in amino acids and fatty acids profiles of muxama and other tunabased cured products during the processes described above have not been studied fully. Those characteristics are relevant if one considers the nutritional composition of tuna muscle, high protein, and fat content and the increased susceptibility to deterioration (bacterial-mediated decarboxylation of histidine into histamine) and to hydrolysis and oxidation, respectively.

Furthermore, it could be interesting to explore the kinetics and effects of "innovative" approaches to the "salting stage", e.g., by way of partial replacement of sodium-based salt with magnesium salts as reviewed by Barat et al. [90] or with the use of vacuum impregnation as studied by Chiralt et al. [113]. In addition to technological advancements, improvements in the efficiency and efficacy of existing methodologies can be achieved by optimization of salting conditions thru more complex experimental designs such as response surface methodology (RSM) [114-116], for example, as carried out by Corzo et al. [117] for catfish.

Moreover, using the approach of Kohsaka et al. [105] to study the relationships between traditional and modern scientific knowledge regarding the production of muxama in South Portugal and Spain and the analysis of certification at regional/landscape/seascape and product levels (sensu [107]) are interesting follow-up studies.

In Europe, there is a growing interest in traditional fish products derived from local species and prepared with ancient, traditional recipes [51]. Researching the more appropriate and effective combination of processing conditions to obtain a product with optimal chemical, microbiological, and sensory characteristics not only allows to provide producers with improved criteria for traditional practices using 
standardized procedures but also represents a basis for product valorization [51]. Moreover, as recapped by Aníbal and Esteves [93], traditional products tend to disappear once producers pass away or production and trade is no longer lucrative. Understanding how traditional products, such as the muxama and other tuna-based cured products aforementioned, are processed and consumed is a first step to ensure they will be produced in the future. Besides contributing to the preservation of (collective) heritage and culture, those products can play an important part in the sustainable development of populations and regions.

\section{Abbreviations \\ $a_{w}$ : Water activity; BCE: Before Common Era; CE: Common Era; EU: European Union; FAO: Food and Agriculture Organization of the United Nations; MAPAMA: Ministry of Agriculture and Fisheries, Food and Environment (Spain); PDO: Protected Designation of Origin; PGI: Protected Geographical Indication; TSG: Traditional Specialty Guaranteed}

\section{Acknowledgements}

We thank the Editor of JEFO and the Reviewers for pertinent comments and suggestions that considerably improved the manuscript.

\section{Authors' contributions}

Authors contributed equally to conceive the study and write/revise the manuscript. All authors read and approved the final manuscript.

\section{Funding}

This study received national funds from FCT-Foundation for Science and Technology (Portugal) [UID/Multi/04326/2019] (EE) and [UID/MAR/00350/ 2019 CIMA] (JA)

\section{Availability of data and materials}

Not applicable

\section{Competing interests}

The authors declare that they have no competing interests.

\section{Author details}

${ }^{1}$ Departamento de Engenharia Alimentar, Instituto Superior de Engenharia, Universidade do Algarve, Faro, Portugal. ${ }^{2}$ CCMAR, Centro de Ciências do Mar, Universidade do Algarve, Faro, Portugal. ${ }^{3} \mathrm{CIMA}$ — Centro de Investigação Marinha e Ambiental, Universidade do Algarve, Faro, Portugal.

\section{Received: 4 September 2019 Accepted: 9 October 2019}

Published online: 02 December 2019

\section{References}

1. Carlucci D, Nocella G, De Devitiis B, Viscecchia R, Bimbo F, Nardone G, et al. Consumer purchasing behaviour towards fish and seafood products. Patterns and insights from a sample of international studies. Appetite. 2015; 84:212-27. https://doi.org/10.1016/j.appet.2014.10.008.

2. Vanhonacker F, Pieniak Z, Verbeke W. European consumer perceptions and barriers for fresh, frozen, preserved and ready-meal fish products. Br Food J. 2013;115:508-25. https://doi.org/10.1108/00070701311317810.

3. Verbeke W, Sioen I, Pieniak Z, Van Camp J, De Henauw S. Consumer perception versus scientific evidence about health benefits and safety risks from fish consumption. Public Health Nutr. 2005;8:422-9. https://doi.org/10. 1079/PHN2004697.

4. FAOSTAT. Food Supply - Livestock and Fish Primary Equivalent 2018. http:// www.fao.org/faostat/en/\#data (accessed December 21, 2017).

5. Almeida C, Karadzic V, Vaz S. The seafood market in Portugal: driving forces and consequences. Mar Policy. 2015;61:87-94. https://doi.org/10.1016/j. marpol.2015.07.012.

6. Cardoso C, Lourenço H, Costa S, Gonçalves S, Nunes ML. Survey into the seafood consumption preferences and patterns in the portuguese population. Gender and regional variability. Appetite. 2013;64:20-31. https:// doi.org/10.1016/j.appet.2012.12.022.
7. Observatorio de Precios de los Alimentos. Atún blanco o Bonito. Precios semanales en la cadena de comercialización [Albacore or bonito. Weekly prices in the marketing chain] 2012. https://www.mapa.gob.es/es/ alimentacion/servicios/observatorio-de-precios-de-los-alimentos/ AtunBlancoo Bonito_tcm30-128566.pdf (accessed March 1, 2019).

8. FAO (Food and Agriculture Organization). FAO report. Rome, Italy: FAO Fisheries and Aquaculture Department, Food and Agriculture Organization of the United Nations; 2016. doi:92-5-105177-1.

9. Randall D, Burggren WW, French K. Eckert animal physiology. 5th ed. W. H. Freeman, Macmillan Learning: New York, USA; 2002.

10. FAO (Food and Agriculture Organization). Fishery statistical collections. Global Production. 2017. http://www.fao.org/fishery/statistics/globalproduction/en (accessed December 21, 2017).

11. INE (Instituto Nacional de Estatística). Produção dos estabelecimentos de aquicultura (t) por Tipo de água (aquicultura), Regime de exploração e Espécie (pesca e aquicultura) [Production of aquaculture establishments (t) by Type of water (aquaculture), Regime of exploitation and Species (fishing and aquaculture)]. 2018. https://www.ine.pt/xportal/xmain?xpid=INE\&xpgid= ine_indicadores\&indOcorrCod=0001474\&contexto=bd\&selTab=tab2 (accessed February 1, 2018).

12. González JAL, Acevedo JMR. Series históricas de capturas del atún rojo en las almadrabas del Golfo de Cádiz (Siglos XVI-XXI) [Historical series of catches of bluefin tuna in the almadrabas of the Gulf of Cádiz (16th-21st centuries)]. Collect Vol Sci Pap ICCAT. 2012;67:139-74.

13. EUMOFA (European Market Observatory for Fisheries and Aquaculture). Observatório do Mercado Europeu da Pesca e da Aquicultura 2018. http:// www.eumofa.eu (accessed February 16, 2018).

14. FAO (Food and Agriculture Organisation). Perfiles sobre la pesca y la acuicultura por países. El Reino de España [Profiles on fishing and aquaculture by countries. The Kingdom of Spain]. 2011. http://www.fao.org/fishery/facp/ ESP/es\#CountrySector-ProductionSector (accessed February 6, 2018).

15. GLOBEFISH. Perspectiva general del mercado mundial de atún [Overview of the world tuna market]. 2017. http://www.fao.org/in-action/globefish/fisheryinformation/resource-detail/es/c/880749/ (accessed February 6, 2018).

16. INE (Instituto Nacional de Estatística). Estatísticas da Pesca 2016 [Fisheries Statistics 2016]. Lisboa, Portugal: Instituto Nacional de Estatística/Direção-Geral de Recursos Naturais, Segurança e Serviços Marítimos; 2017. doi:0377-225-X.

17. MAPAMA (Ministerio de Agricultura, Pesca y Alimentación). Estadísticas pesqueras: Productos de las industrias de procesado de pescado [Fishery statistics: Products from the fish processing industries]. 2017. https://www.mapa.gob.es/images/es/201 7_01_productos_tcm30-121875.pdf (accessed January 6, 2019).

18. Taconet P, Chassot E, Guitton J, Palma C, Fiorellato F, Anello E, et al. Global database and common toolbox for tuna fisheries. Collect Vol Sci Pap ICCAT. 2017;73:3327-37.

19. Tunipex 2011. http://www.tunipex.eu (accessed January 6, 2019).

20. OPP51. Organización de Productores Pesqueros de Almadraba. 2015. http:// www.atunrojosalvajedealmadraba.com (accessed January 6, 2019).

21. PNRF. (Parque Natural da Ria Formosa). A pesca do atum no Algarve [Tuna fishing in the Algarve]. Parque Natural da Ria Formosa, Instituto de Conservação da Natureza: Olhão, Portugal; 1996.

22. La Chanca n.d. https://www.lachanca.com/las-almadrabas/ (accessed February 14, 2018).

23. Dufour F, Arrizabalaga $H$, Irigoien $X$, Santiago J. Climate impacts on albacore and bluefin tunas migrations phenology and spatial distribution. Prog Oceanogr. 2010;86:283-90.

24. Santos LFR. A pesca do atum no Algarve [The tuna fishery in the Algarve]. Edição com apoio do Parque Natural da Ria Formosa: Olhão, Portugal; 1989.

25. Lã A, Vicente L. O Atum Esquecido [The forgotten tuna]. Faro, Portugal: Universidade do Algarve; 1993.

26. Rebelo MJF. As indústrias da pesca e conservas de atum no Algarve do Século XX [The tuna fishing and canning industries in the Algarve of the 20th century]. Faro, Portugal: Universidade do Algarve; 2010.

27. Florido del Corral D. Las almadrabas suratlánticas andaluzas: historia, tradición y patrimonio (ss. XVIII-XXI) [The Andalucian almadrabas: history, tradition, and heritage (18th-21st centuries)]. Sevilla, España: Editorial Universidad de Sevilla; 2017.

28. Longo SB, Clark B. The commodification of bluefin tuna: the historical transformation of the mediterranean fishery. J Agrar Change. 2012;12:20426. https://doi.org/10.1111/j.1471-0366.2011.00348.x.

29. GLOBEFISH. The canned seafood sector in Spain. n.d. http://www.fao.org/in-action/ globefish/fishery-information/resource-detail/en/c/338172/ (accessed January 9, 2018). 
30. Gallart-Jornet L, Roberto IE, Maupoei PF. La salazón de pescado, una tradición en la dieta mediterránea [The salting of fish, a tradition in the Mediterranean diet]. Valencia, España: Editorial de la Universidad Politécnica de Valencia; 2005

31. Sahrhage D, Lundbeck J. A history of fishing. Berlin, Heidelberg: SpringerVerlag; 1992. https://doi.org/10.1007/978-3-642-77411-9.

32. Bernardes JP. Consumo e transformação de peixe entre o mundo romano e o islâmico [Fish consumption and processing between the Roman and Islamic worlds]. In: Gómez Martinez S, editor. Memória dos Sabores do Mediterrâneo [Memory of Mediterranean Flavors]. Mértola, Portugal: Campo Arqueológico de Mértola / Centro de Estudos Arqueológicos das Universidades de Coimbra e Porto; 2015, p. 55-68. doi:http://hdl.handle.net/10400.1/10575.

33. Bernal D, Díaz JJ, Expósito JA, Palacios V, Vargas JM, Lara M, et al. Atunes y garum en Baelo Claudia: nuevas investigaciones [Tunas and garum in Baelo Claudia: new research]. Al Qantir. 2018;21:73-86.

34. Alasalvar C, Shahidi F, Miyashita K, Wanasundara U. Handbook of seafood quality, safety and health applications. Chichester, UK: John Wiley \& Sons; 2011.

35. Boziaris IS. Seafood processing. technology, quality and safety. Chichester, UK: John Wiley \& Sons, Ltd.; 2014

36. Hall GM. Fish processing technology. 2nd ed. London: Blackie Academic and Professional/Chapman \& Hall; 1997

37. Hall GM. Fish processing. Sustainability and new opportunities. Chichester, United Kingdom: Wiley-Blackwell Publishing Ltd; 2011.

38. Huss HH. Quality and quality changes in fresh fish. FAO Fish Tech Pap. 1995:348:1-195.

39. Huss HH, Ababouch L, Gram L. Assessment and management of seafood safety and quality. FAO Fish Tech Pap. 2003;444:1-230.

40. Nollet LML, Toldrá F. Handbook of seafood and seafood products analysis. Boca Raton, Florida, USA: CRC Press Inc.; 2010.

41. Rehbein H, Oehlenschlager J. Fishery products. Quality, safety and authenticity. Wiley-Blackwell: Chichester, UK; 2009.

42. Genç IY, Esteves E, Diler A. Handbook of seafood: quality and safety maintenance and application. New York, USA: Nova Science Publishers, Inc; 2016.

43. Esteves E, Diler A, Genç IY. General introduction to seafood quality and safety maintenance and applications. In: Genç IY, Esteves E, Diler A, editors. Handbook of seafood: quality and safety maintenance and application. New York, USA: Nova Science Publishers Inc.; 2016. p. 1-11.

44. Sen DP. Advances in fish processing technology. New Delhi, India: Allied Publishers; 2005

45. Lowry D. The connoisseur's guide to sushi. Boston: The Harvard Common Press; 2005.

46. Matsuda Y. History of fish marketing and trade with particular reference to Japan. In: Johnston RS, Shriver AL, editors. Microbehavior and macroresults: Proceedings of the Tenth Biennial Conference of the International Institute of Fisheries Economics and Trade, July 10-14 2000. Corvalis, Oregon, USA: International Institute of Fisheries Economics and Trade (IIFET); 2001, p. 23-38. https://irlibrary. oregonstate.edu/concern/conference_proceedings_or_journals/2227mq47q

47. Tsuji S. Japanese cooking: a simple art. Kodansha International: Tokyo, Japan; 2012.

48. Vaudagna SR, Gonzalez CB, Guignon B, Aparicio C, Otero L, Sanz PD. The effects of high hydrostatic pressure at subzero temperature on the quality of ready-to-eat cured beef carpaccio. Meat Sci. 2012;92:575-81. https://doi. org/10.1016/j.meatsci.2012.06.002.

49. Fernandes da Costa PM, Hu W, Pan M. Ahi poke (raw tuna salad) consumption and consumer characteristics in hawaii. Aquac Econ Manag. 2011;15:302-15. https://doi.org/10.1080/13657305.2011.624576.

50. Chung T, Samuels D. Korean table: from barbecue to bibimbap 100 easy-toprepare recipes. Clarendon, USA: Tuttle Publishing; 2015.

51. Moretti VM, Vasconi M, Caprino F, Bellagamba F. Fatty acid profiles and volatile compounds formation during processing and ripening of a traditional salted dry fish product. J Food Process Preserv. 2017;41:e13133. https://doi.org/10.1111/jfpp.13133.

52. Frawley JK, Dyson LE, Underwood J. Rewriting, redesigning and reimagining the recipe for more sustainable food systems. Proceedings of the 26th Australian Computer-Human Interaction Conference on Designing Futures: the Future of Design (OzCHI '14), December 2-5, 2014. Sydney, NSW Australia: ACM; 2014. p. 366-9. https://doi.org/10.1145/2686612.2686667.

53. Silver JJ, Hawkins R. "I'm not trying to save fish, I'm trying to save dinner": media, celebrity and sustainable seafood as a solution to environmental limits. Geoforum. 2017;84:218-27. https://doi.org/10.1016/j.geoforum.2014.09.005.

54. Sloan D. Culinary taste: consumer behaviour in the international restaurant sector. Elsevier Butterworth-Heinemann: Oxford, UK; 2004.
55. Notaker H. Food culture in Scandinavia. Westport, Connecticut, USA: Greenwood Press; 2009.

56. Rodriguez D. The great ceviche book. New York, USA: Ten Speed Press; 2010

57. Werner E, Henry M. Hartwood: bright, wild flavors from the edge of the Yucatán. New York, USA: Artisan Books; 2015.

58. Gutierrez SA. Latin american street food: the best flavors of markets, beaches, and roadside stands from Mexico to Argentina. Chapel Hill, USA: University of North Carolina Press; 2013.

59. Doe PE, Olley J. Drying and dried fish products. In: Sikorski ZE, editor. Seafood resources: nutrition, composition and preservation. Boca Raton, Florida: CRC Press Inc:; 1990. p. 125-45.

60. Doe PE. Fish drying \& smoking: production and quality. Lancaster, USA: Technomic Publishing Company, Inc.; 1998.

61. Nguyen MV, Arason S, Eikevik TM. Drying of fish. In: Boziaris IS, editor. Seafood processing technology, quality and safety. Chichester, UK: John Wiley \& Sons, Ltd.; 2014. p. 161-75.

62. Venugopal $V$, Shahidi F. Traditional methods to process underutilized fish species for human consumption. Food Rev Int. 1998;14:35-97. https://doi. org/10.1080/87559129809541149.

63. Horner WFA. Preservation of fish by curing (drying, salting and smoking). In: Hall GM, editor. Fish processing technology. London: Blackie Academic and Professional/ Chapman \& Hall; 1997. p. 32-73. https://doi.org/10.1007/978-1-4613-1113-3.

64. Sabarez H. Drying of food materials. Ref Modul Food Sci. 2016:1-10. https:// doi.org/10.1016/B978-0-08-100596-5.03416-8.

65. Kurlansky M. Salt. A world history. London, UK: Vintage Books; 2003.

66. Driscoll R. Food dehydration. In: Smith JS, Hui YH, editors. Food processing: principles and applications. USA: Blackwell Publishing Ltd; 2004. p. 31-44.

67. Doe PE. Fish drying. In: Bremner HA, editor. Safety and quality issues in fish processing. Cambridge, UK: Woodhead Publishing Ltd.; 2002. p. 350-9.

68. Rahman MS, Perera C. Drying and food preservation. In: Rahman MS, editor. Handbook of food preservation. 2nd ed. Boca Raton, Florida, USA: CRC Press Inc:; 2007. p. 403-32. https://doi.org/10.1017/CBO9781107415324.004.

69. Smith PG. Introduction to food process engineering. 2nd ed. Springer Science+ Business Media LLC: New York, USA; 2011. https:/doi.org/10.1007/978-1-4419-7662-8.

70. Ismail N, Wootton M. Fish salting and drying: a review. ASEAN Food J. 1992:7:175-83.

71. Zaki MS, El Mansy HAH, Hassan YM, Rahma EHA. Effect of nisin in saturated brine and storage on the quality of dried bolti fish (Tilapia nilotica). Nahrung. 1976;20:691-7.

72. Turan $H$, Erkoyuncu I. Salting technology in fish processing. In: Bhat R, Alias AK, Paliyath G, editors. Progress in food preservation. Chichester, UK: WileyBlackwell; 2012. p. 297-314.

73. Wang $Y$, Zhang M, Mujumdar AS. Trends in processing technologies for dried aquatic products. Dry Technol. 2011;29:382-94. https://doi.org/10. 1080/07373937.2011.551624

74. Driscoll R. Dehydration. In: Clark S, Jung S, Lamsal B, editors. Food processing: principles and applications. Chichester, UK: John Wiley \& Sons, Ltd.; 2014. p. 61-78.

75. Rahman MS. Drying of fish and seafood. In: Mujumdar AS, editor. Handbook of industrial drying. Boca Raton, Florida, USA: CRC Press Inc:; 2015. p. 545-57.

76. Albarracín W, Sánchez IC, Grau R, Barat JM. Salt in food processing usage and reduction: a review. Int J Food Sci Technol. 2011;46:1329-36. https:// doi.org/10.1111/j.1365-2621.2010.02492.x.

77. Sampels S. The effects of processing technologies and preparation on the final quality of fish products. Trends Food Sci Technol. 2015;44:131-46. https://doi.org/10.1016/j.tifs.2015.04.003.

78. Venugopal $V$. Seafood processing: adding value through quick freezing, retortable packaging and cook-chilling. Boca Raton, Florida, USA: CRC Press; 2005.

79. Rahman MS. Osmotic dehydration of foods. In: Rahman MS, editor. Handbook of food preservation. 2nd ed. Boca Raton, Florida, USA: CRC Press Inc.; 2007. p. 433-46. https://doi.org/10.1016/S0963-9969(00)00143-5.

80. Bellagha S, Sahli A, Farhat A, Kechaou N, Glenza A. Studies on salting and drying of sardine (Sardinella aurita): Experimental kinetics and modeling. J Food Eng. 2007;78:947-52. https://doi.org/10.1016/j.jfoodeng.2005.12.008.

81. Boudhrioua N, Djendoubi N, Bellagha S, Kechaou N. Study of moisture and salt transfers during salting of sardine fillets. J Food Eng. 2009;94:83-9. https://doi.org/10.1016/j.jfoodeng.2009.03.005.

82. Esteves E, Aníbal J. Optimization of processing conditions of traditional cured tuna loins-muxama. Fishes. 2018;3:3. https://doi.org/10.3390/ fishes3010003.

83. Esteves E, Lourenço H, Rosa I, Aníbal J. Physicochemical and microbiological changes in dried small-spotted catshark (Scyliorhynus canicula): contributing to the 
developing an alternative shark-based salted-dried seafood product. J Aquat Food Prod Technol. 2018;27:176-84. https://doi.org/10.1080/10498850.2017.1417339.

84. Oliveira H, Pedro S, Nunes ML, Costa R, Vaz-Pires P. Processing of salted cod (Gadus spp.): a review. Compr Rev Food Sci Food Saf. 2012;11:546-64. https://doi.org/10.1111/j.1541-4337.2012.00202.x.

85. Jain D, Pathare PB. Study the drying kinetics of open sun drying of fish. J Food Eng. 2007;78:1315-9. https://doi.org/10.1016/j.jfoodeng.2005.12.044.

86. Sobukola OP, Olatunde SO. Effect of salting techniques on salt uptake and drying kinetics of African catfish (Clarias gariepinus). Food Bioprod Process. 2011:89:170-7. https://doi.org/10.1016/j.fbp.2010.06.002.

87. Graiver N, Pinotti A, Califano A, Zaritzky N. Mathematical modeling of the uptake of curing salts in pork meat. J Food Eng. 2009;95:533-40. https://doi. org/10.1016/j.jfoodeng.2009.06.027.

88. Barat JM, Grau R. Thawing and salting studies of dry-cured tuna loins. J Food Eng. 2009;91:455-9. https://doi.org/10.1016/j.jfoodeng.2008.09.024.

89. Gallart-Jornet L, Barat JMM, Rustad T, Erikson U, Escriche I, Fito P. A comparative study of brine salting of Atlantic cod (Gadus morhua) and Atlantic salmon (Salmo salar). J Food Eng. 2007;79:261-70. https://doi.org/ 10.1016/j.jfoodeng.2006.01.053.

90. Barat J-M, Pérez-Esteve E, Aristoy M-C, Toldrá F. Partial replacement of sodium in meat and fish products by using magnesium salts. A review. Plant Soil. 2013;368:179-88. https://doi.org/10.1007/s11104-012-1461-7.

91. Wikipedia The Free Encyclopedia. Dried fish 2018. https:/en.wikipedia.org/wiki/Dried_fish 0 .

92. Esteves E. Fish products from south Portugal: dried litão, tuna muxama, and canned mackerel. In: Cruz RMS, Vieira MC, editors. Mediterranean food: composition and processing. Boca Raton, Florida, USA: CRC Press Inc.; 2017. p. 65-101.

93. Aníbal J, Esteves E. Muxama and estupeta: traditional food products obtained from tuna loins in South Portugal and Spain. In: Kristbergsson K, Oliveira J, editors. . New York: Springer: Traditional food products. General and Consumer Aspects; 2016. p. 271-4.

94. Mujaffar S, Sankat CK. The air drying behaviour of shark fillets. Can Biosyst Eng. 2005;47:3.11-21

95. Guizani N, Al-Shoukri AO, Mothershaw A, Rahman MS. Effects of salting and drying on shark (Carcharhinus sorrah) meat quality characteristics. Dry Technol. 2008;26:705-13. https://doi.org/10.1080/07373930802046294.

96. Darvishi H, Azadbakht M, Rezaeiasl A, Farhang A. Drying characteristics of sardine fish dried with microwave heating. J Saudi Soc Agric Sci. 2013;12: 121-7. https://doi.org/10.1016/j.jssas.2012.09.002

97. Yubero ID. Sabores de Andalucía [Flavors of Andalucía]. Distrib y Consum 2008:Septiembre:116-125.

98. Andalucia.com. El ronqueo - from whole tuna to tasty tapas, in minutes. 2014. http://blog.andalucia.com/wp-content/uploads/ronqueo-diagram-ElCampero.jpg (accessed January 30, 2018).

99. Productos de Almadraba SL. Despiece del atún rojo salvaje de almadraba [Quartering of wild bluefin tuna from almadraba]. 2013. http:// productosdealmadraba.com/254-large_default/despiece-del-atun-rojosalvaje-de-almadraba.jpg (accessed February 1, 2018).

100. Bluefin-big.jpg 2018. https://commons.wikimedia.org/w/index.php?curid = 86038 (accessed January 30, 2018).

101. Llorca Ibi FX. El lenguaje del atún, una creación sociocultural mediterránea [The language of tuna, a Mediterranean socio-cultural creation]. Rev Dialectol y Tradic Pop. 2017;72:221-44. https://doi.org/10.3989/rdtp.2017.01.009.

102. EU (European Union). Commission implementing regulation (EU) 2015/2110 of 12 November 2015 entering a name in the register of protected designations of origin and protected geographical indications [Mojama de Barbate (PGI)]. Off J Eur Union 2015;L 306:1-2.

103. EU (European Union). Commission implementing regulation (EU) 2016/199 of 9 February 2016 entering a name in the register of protected designations of origin and protected geographical indications (Mojama de Isla Cristina (PGI)). Off J Eur Union 2016;L 39:4.

104. Lindkvist KB, Gallart-Jornet L, Stabell MC. The restructuring of the Spanish salted fish market. Can Geogr-Géogr Can. 2008;52:105-20. https://doi.org/10. 1111/j.1541-0064.2008.00203.x.

105. Kohsaka R, Tomiyoshi M, Saito O, Hashimoto S, Mohammend L Interactions of knowledge systems in shiitake mushroom production: a case study on the Noto Peninsula, Japan. J For Res-Japan. 2015;20:453-63. https//doi.org/10.1007/s10310-015-0491-4.

106. Uchiyama Y, Matsuoka H, Kohsaka R. Apiculture knowledge transmission in a changing world: Can family-owned knowledge be opened? J Ethn Foods. 2017:4:262-7. https://doi.org/10.1016/J.JEF.2017.09.002.

107. Kajima S, Tanaka Y, Uchiyama Y. Japanese sake and tea as place-based products: a comparison of regional certifications of globally important agricultural heritage systems, geopark, biosphere reserves, and geographical indication at product level certification. J Ethn Foods. 2017;4:80-7. https:// doi.org/10.1016/J.JEF.2017.05.006.

108. EU (European Union). Regulation (EU) No. 1151/2012 of the European Parliament and of the Council of 21 November 2012 on quality schemes for agricultural products and foodstuffs. Off J Eur Union 2012;L 343:1-29.

109. García Henche B, Sánchez MI. La ruta milenaria del atún: Lecciones aprendidas de un producto turístico experiencial en el litoral gaditano. Int J World Tour. 2018;5:1-15. https://doi.org/10.12795/ijwt.2018.109.01.

110. DGADR. (Direção-Geral da Agricultura e do Desenvolvimento Rural). Produtos tradicionais portugueses: estupeta de atum [Traditional portuguese products: estupeta de atum]. Ministério da Agricultura, Desenvolvimento Rural e Pescas, Secretaria de Estado do Desenvolvimento Rural, Direção-Geral do Desenvolvimento Rural: Lisboa, Portugal; 2001.

111. Garaffo MA, Vassallo-Agius R, Nengas Y, Lembo E, Rando R, Maisano R, et al. Fatty acids profile, atherogenic (IA) and thrombogenic (IT) health lipid indices, of raw roe of blue fin tuna (Thunnus thynnus L.) and their salted product "Bottarga". Food Nutr Sci. 2011;2:736-43. https:/doi.org/10.4236/fns.2011.27101.

112. Collignan A, Bohuon P, Deumier F, Polign I, Poligné I. Osmotic treatment of fish and meat products. J Food Eng. 2001;49:153-62. https://doi.org/10. 1016/S0260-8774(00)00215-6.

113. Chiralt A, Fito P, Barat JM, Andrés A, González-Martínez C, Escriche I, et al. Use of vacuum impregnation in food salting process. J Food Eng. 2001;49: 141-51. https://doi.org/10.1016/S0260-8774(00)00219-3.

114. Anderson MJ, Whitcomb PJ. RSM simplified: optimizing processes using response surface methods for design of experiments. New York, USA: Productivity Press; 2005.

115. Granato D, Ares G. Mathematical and statistical methods in food science and technology. Oxford, UK: IFT Press and Wiley-Blackwell; 2014. https://doi. org/10.1002/9781118434635.

116. Montgomery DC. Design and analysis of experiments. 8th ed. New Jersey, USA: John Wiley \& Sons Inc.; 2013. https://doi.org/10.1198/tech.2006.s372.

117. Corzo O, Bracho N, Rodríguez J, Arias JM. Optimizing salting and smoking of catfish (Bagre marinus) using response surface methodology. J Aquat Food Prod Technol. 2015;25:358-72. https://doi.org/10.1080/10498850.2013.855286.

\section{Publisher's Note}

Springer Nature remains neutral with regard to jurisdictional claims in published maps and institutional affiliations.

Ready to submit your research? Choose BMC and benefit from:

- fast, convenient online submission

- thorough peer review by experienced researchers in your field

- rapid publication on acceptance

- support for research data, including large and complex data types

- gold Open Access which fosters wider collaboration and increased citations

- maximum visibility for your research: over $100 \mathrm{M}$ website views per year

At $\mathrm{BMC}$, research is always in progress.

Learn more biomedcentral.com/submissions 